\title{
Chapter 18 \\ International Students in Australia, Employability and Cultural Competence
}

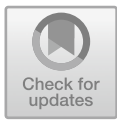

\author{
Tran Nguyen and Donna Hartz
}

\section{Introduction}

Employability is often defined as "a set of achievements — skills, understandings and personal attributes - that makes graduates more likely to gain employment and be successful in their chosen occupations, which benefit themselves, the workforce, the community and the economy" (Yorke, 2006, p. 8). The debate on employability has so far been dominated by the discourse of skills acquisition (see Fugate, Kinicki, \& Ashforth, 2004; McQuaid \& Lindsay, 2005). Different terms have been used to describe the desired skills to promote employability, such as "personal skills", "transferable skills", "generic skills" or "core skills". Nonetheless, this approach has been criticised for neglecting other factors that may also contribute to employability; for example, discriminatory practices by employers (see Holmes, 2013) which affect employability, particularly for international students.

McQuaid and Lindsay (2005) shift the attention away from the skill discourse and contend that employability is not simply a measure of an individual's potential for employment, but also the social and economic context which enables this potential to be realised or otherwise. Tomlinson (2017) proposes the use of the capital concept in viewing employability and argues that employability includes (a) human capital, which are hard skills and technical knowledge acquired through degrees, and other career-related awareness and skills; (b) social capital which is acquired through social relations and contacts; (c) cultural capital which include cultural knowledge, behaviours, and awareness that make students attractive to employers; (d) identity

\section{T. Nguyen $(\otimes)$}

National Centre for Cultural Competence, The University of Sydney, Sydney, NSW, Australia

e-mail: tran.nguyen1@sydney.edu.au

D. Hartz

Faculty of Health, Charles Darwin University, Darwin, NT, Australia

J. Frawley et al. (eds.), Cultural Competence and the Higher Education Sector, https://doi.org/10.1007/978-981-15-5362-2_18 
capital, which refers to a person's sense of personal identity around targeted employment(s); and psychological capital, or the level of resilience and adaptability during job search.

Current research and media reports suggest that international students are facing critical challenges in securing employment in Australia, as students or postgraduation (Blackmore et al., 2014; Campbell, Boese, \& Tham, 2016; Clibborn, 2015; Gribble, 2014; Murray, Blackmore, Gribble, \& Hall, 2012; Nyland, ForbesMewett, \& Marginson, 2010; Robertson, 2011, 2013). This situation raises a pertinent question about ways to enhance employability for this group of students. International students' negative experiences regarding employment opportunities adversely affect their well-being and satisfaction when studying in Australia (Blackmore et al., 2014; Gribble et al., 2015; Nyland et al., 2010). Amid an increasingly competitive environment in the international education market, this may substantially affect other international students' decision when considering whether or not to choose Australia as their learning space. Countries such as the USA, Germany, Austria, the UK and Canada, as well as Australia, are redesigning migration policy in order to facilitate better job search opportunities for international students (Hawthorne \& To, 2014).

The current limited solutions to address international students' employability challenges have, to date, largely been adopted from institutional or legal approaches (Gardner, 2004; Gribble et al., 2015; Reilly, 2012). Gribble, Blackmore, \& Rahimi, (2017) suggest that educational institutions in Australia can improve their employment service support for international students through different ways, such as providing better opportunities for students to attend work integrated learning programmes or enhancing the connectedness of international students to the local community. Reilly (2012) observes that currently, no higher education institutions offer a dedicated employment service to international students. In most cases, such support is offered under the form of educational seminars that provide some information for students and family members; for example, work restrictions in visas for students, or on Australian employment rights generally (including minimum wages), and the role of the Fair Work Ombudsman. Other scholars have called for more effective workplace regulations (Campbell et al., 2016; Clibborn, 2015; Reilly, 2012). Reilly (2012) suggests significant reform regarding the regulation of the work entitlements and protections of international student-workers in Australian migration and industrial law. Campbell et al. (2016) draw attention to employer labour-use strategies such as underpayment. Campbell et al. (2016), in particular, highlight the importance of investigating international students' individual agency to address employment challenges.

Research has started to highlight the importance of cultural competence, and its associated self-efficacy and interpersonal skills, in enhancing employability for students (Baumann \& Vialleton, 2017; Busch, 2009; Fielden, 2007; Jones, 2013). Cultural competence, or the capacity to function effectively in cross-cultural settings, has been claimed as a core employability attribute (Baumann \& Vialleton, 2017; Busch, 2009; Fielden, 2007; Jones 2013; Potgieter \& Coetzee, 2013; Webb, 2005). Nilsson and Ripmeester (2016) assert that it is important to help international 
students to understand the cultural differences that play a role in job hunting, as well as understanding what skills employers are looking for in particular countries and sectors. However, little research has explored how cultural competence contributes to enhancing international students' employability and employment in Australia. This chapter addresses this literature lacuna by identifying dimensions of cultural competence that can enable international students to enhance employment opportunities.

In this chapter, we discuss the literature relating to international students in Australia and their employment experience. Relevant studies from other countries such as the USA and Canada are also reviewed, given the similar challenges faced by international students in those countries. This chapter does not specifically concentrate on issues related to international students' learning outcomes. Initially, the literature's key search terms included employability, international students in Australia, international students' employment experiences and cultural competence. This search also then allowed the researchers to review the related literature such as international students' connectedness and identity, or international students and immigration. A total of 68 items were reviewed: 48 peer review articles, 5 research reports, and 15 items that include books, book chapters and media articles. Of the 68 items:

- twenty-eight peer review articles focus on international students' employment and cross-cultural interacting experiences in Australia,

- six peer review articles discuss international students' related experiences in the USA and Canada,

- five reports exclusively concentrate on international students and their work experience in Australia, and

- fourteen peer review articles centre on the cultural competence concept.

Research data was analysed inductively and thematically, which allowed an identification of important emerging themes. As a starting point, the concept of cultural competence is introduced. An overview of international students and their employability challenges in Australia is then discussed. Next, the dimensions of cultural competence that can assist international students in becoming more employable when looking for work in Australia are presented.

\section{Dimensions of Cultural Competence}

Cultural competence refers to the capacity to work effectively in cross-cultural settings (Campinha-Bacote, 2016; Cross, Bazron, Dennis, \& Isaacs, 1989; Deardoff $\&$ Jones, 2012). It is also known under different terms such as intercultural competencies (Bennett, 2009), multicultural effectiveness (Van de Zee \& Van Oudenhoven, 2000) and cultural intelligence (Ang, Van Dyne, \& Koh, 2006). The traditional way of 
conceptualising cultural competence is using the framework of knowledge, attitudes and skills (Bennett, 2009; Carpenter, 2016; Deardoff \& Jones 2012).

Different aspects of cultural competence can be found in the current literature (Bennett, 2009; Van de Zee \& Van Oudenhoven, 2000). This chapter, however, will only review the specific aspects of cultural competence that we argue are essential to advance employability for international students in Australia. These include knowledge, social initiatives, flexibility, emotional stability, self-reflection, and the ability to see multiple worldviews (Ang et al., 2006; Campinha-Bacote, 2016; Olson, Bidewell, Dune, \& Lessey, 2016; Sherwood \& Russell-Mundine, 2017; SNAICC, 2012; Van de Zee \& Van Oudenhoven, 2000). Knowledge is viewed as one of the most critical elements of cultural competence (Ang et al., 2006; Campinha-Bacote, 2016; Carpenter, 2016). Such knowledge can include understanding one's history, culture, customs, and beliefs as well as those of other people. Ang et al. (2006) also emphasise the importance of developing knowledge about the economic, legal and social systems in other cultures.

Van der Zee and Van Oudenhoven (2000) highlight the importance of what they term as "social initiative", defined as a tendency to actively approach social situations and to take the initiative. This aspect of cultural competence also refers to individuals' capacity to build up social networks and lead social action. Emotional stability (Ang et al., 2006; Van de Zee \& Van Oudenhoven, 2000) is also viewed as a critical dimension of cultural competence as it reflects individuals' tendency to remain calm in stressful situations, which can help them to better deal with novel and unfamiliar intercultural interactions.

Another significant part of cultural competence that has been identified in the literature is "flexibility", which refers to the capability of adjusting oneself cognitively and behaviourally to new situations (Shaffer, Harrison, Gregersen, \& Black, 2006; Van de Zee \& Van Oudenhoven, 2000). This is because flexibility allows people to actively employ different strategies to deal with cross-cultural situations in case familiar ways of handling things may no longer work (Van de Zee, Zaal, \& Piekstra, 2003). Self-reflection is also viewed as an important skill to build cultural competence as it helps to develop a better understanding about oneself, one's own cultures and others' cultures (Olson et al., 2016).

Equally important in developing cultural competence is the ability to recognise different worldviews (SNAICC, 2012). "Habitus" (Bourdieu, 1990) is an important concept that can help to explain the existence of multiple worldviews. Habitus, according to Bourdieu (1990, p. 56), is "the active presence of the whole past of which it is the product", or "the second nature". Habitus can be found in one's actions, modes of appearance and bearing — posture, manners, ways of speaking — which make social life possible (Bourdieu, 1991, pp. 6-89). It plays the role of developing individuals' attitude towards society and guiding their interaction within what Bourdieu terms "the fields" (e.g. the family or the workplace). The unconscious aspect of habitus may be understood in the sense that the accumulation and acquisition of knowledge are carried out without individuals' clear awareness regarding the future use of such knowledge. Wise (2009) maintains that although Bourdieu never really dealt with 
ethnicity or multiethnic societies, his theory about social fields implies that ethnicities themselves can function as social fields within which hierarchies of position exist and are framed by ethnic habitus.

There have been some critiques of the cultural competence framework. For example, some argue that a focus on developing individual cultural competence can shift the attention away from critical problems such as institutional racism (Pollack, 2004; Razack \& Jeffery, 2002). Harrison and Turner (2011, p. 347) observe that both the literature and policy actors tend to downplay the impact of the organisational context on service delivery; and that instead, cultural competence is presented as predominantly a product of individual behaviour. There are also concerns that cultural competence promotes "Otherness", fuels new forms of racism and reinforces existing inequalities (Harrison \& Turner, 2011; Pon, 2009).

At the same time, the benefits of cultural competence have been acknowledged; for example, cultural competence is found to be effective in improving communication between health providers and patients, leading to clients' higher satisfaction, and resulting in patients' stricter adherence to medical instructions (Betancourt, Green, Carrillo, \& Park, 2005). Cultural competence reportedly plays an important role in the successful adjustment of international students in the host country (Wang, Heppner, Wang, \& Zhu, 2014). In particular, cultural competence has been viewed as a core element of employability attributes (Baumann \& Vialleton, 2017; Busch, 2009; Fielden, 2007; Jones, 2013; Potgieter \& Coetzee, 2013; Webb, 2005). However, little has been known about specific ways in which cultural competence contributes to improving employability for international students in Australia.

\section{Employability Issues Concerning International Students in Australia}

The number of international students in Australia continues to increase. By February 2019 , there were 582,883 students enrolled in different education sectors including higher education, vocational education and training (VET), schools or intensive English language course for overseas students. Top country contributors include China (30\%), India (14\%), Nepal (7\%), Malaysia (4\%) and Vietnam (4\%) (Department of Education and Training, 2019). These statistics demonstrate that international students are predominantly from non-English-speaking backgrounds. Among the most important reasons for this growth include international students' search for not only Australian qualifications, but also relevant skills and work experience beneficial for a career either in Australia, their home country or elsewhere (Gribble et al., 2015). International students on a student visa are limited to working up to 40 hours per fortnight during the semester (Department of Home Affairs, 2019a). Postgraduate research students can work unlimited hours once they have commenced their study in Australia (Department of Home Affairs, 2019b). 
International students in Australia have been found to be either struggling to find jobs that match their qualifications or having to do unskilled labour with low wage rates (Campbell et al., 2016; Clibborn, 2015; Robertson, 2011). Compared to migrants, international graduates earn much lower annual salaries and have lower job satisfaction and less frequent use of their formal qualifications in their current work (Hawthorne, 2010; Hawthorne \& To, 2014). Clibborn (2015) found that $60 \%$ of international students earned less than the legal minimum wage of $\$ 17.29$ per hour. International students also have poorer employment outcomes in comparison with domestic students, especially when they search for jobs in the oversupplied fields of business and commerce, accounting, and information technology (Hawthorne \& To, 2014). It is more challenging for international students qualified with masters by coursework to find jobs, compared with international students who have doctoral qualifications or bachelor degrees (Hawthorne \& To, 2014, 105). International students, regardless of ethnicity or nationality, are experiencing labour market barriers on the basis of their temporary status; overall, casualised/informal and low-skilled work is the most common source of employment. While students from Anglo-Saxon and Anglo-Celtic backgrounds in Australia often do jobs such as tele-sales, fundraising and "mainstream" hospitality jobs, international students tend to work more often in "ethnic" hospitality and retail businesses (Robertson, 2016).

Current research highlights three key factors that explain why international students are facing critical challenges when looking for work in Australia. Those factors include: (a) the Australian public's negative perceptions about international students that are largely constructed by media reports or findings from academic research (Blackmore et al., 2014; Nyland et al., 2009; Robertson, 2011, 2013), which have intensified following the influx of international students enrolling in the VET sectors (Robertson, 2013); (b) the government's current migration policy regarding international students; and (c) employers' unfavourable attitudes towards recruiting international students.

International students are believed to lack cultural competence, and this has been expressed both within and beyond the classroom's context. Regarding their learning experiences, international students are viewed (by teachers and other students) as having limited English skills, low motivation, poor attendance; being largely depending on rote learning; lacking analytical and critical skills; or having awkward ways in classroom participation (Birrell, 2006; Carroll \& Ryan, 2005; Devos, 2003; Tran \& Nyland, 2011). International students are also perceived by others as having weak cross-cultural communications skills; lack of knowledge of, and exposure to, the local labour market and workplace culture; and/or using education solely as a migration pathway (Blackmore et al., 2014; Gribble et al., 2015; Gribble \& McRae, 2017; Jackson, 2017; Marginson, Nyland, Sawir, \& Forbes-Mewett, 2010; Reilly, 2012; Robertson, 2011). Birrell (2006) suggests that many international students' communication capacity is well short of that required to meet Australia's higher education standards or the standards of employers of professionals. According to Gribble et al. (2015), international students are also found to lack "soft skills", as a result of many of them undervaluing the importance of developing such skills and preferring to focus on acquiring technical skills and achieving high grades. 
Furthermore, many international students have little knowledge about the job application process and work culture in Australia, which may differ significantly from the job-seeking approaches and work culture in their home country (Gribble et al., 2015).

Another key factor explaining international students' poor employment outcomes is the Australian Government's current migration policies that no longer favour the link between education and migration (Nyland et al., 2010; Robertson, 2011). In the 1990s, the Australian migration policy was designed to encourage fee-paying international students to apply for permanent residency to fill specific shortages in targeted professions. However, since 2010, the Australian Government has no longer supported such policy and instead has sought to sever the education-migration nexus through different measures, such as requiring employers' sponsorship for graduates and imposing restrictions upon post-study work visas (Gribble \& Blackmore, 2012). Coupled with the current difficult global economic environment conditions, the Australian public's negative perceptions about international students have been argued to be a contributing factor in the development of these migration policies (Robertson, 2011).

Employers in Australia also tend to show a lack of enthusiasm in recruiting international students. In addition to sharing the public's negative perceptions about international students regarding students' communication skills and cultural fit, employers also have doubts about students' long-term work commitment versus the cost of hiring and training those students which may be an unwarranted investment. Additionally, employers may lack appreciation or understanding about international students' international experience, and possibly discriminate against students because of their non-English names (Blackmore et al., 2014; Devos, 2003; Gribble \& McRae, 2017). Research from the USA and Canada also reflects similar perceptions of employers about international students (Bond, Areepattamannil, Brathwaite-Sturgeon, Hayle, \& Malekan, 2007; McFadden \& Seedorff, 2017; Nunes \& Arthur, 2013). McFadden and Seedorff (2017) point further to employers' challenges; for example, the cost of time and paperwork required to hire international students who would require employment visa sponsorship.

In the following sections of this chapter, we discuss different dimensions of cultural competence that we argue are essential to enhance international students' employability in Australia.

\section{Advancing Employability Through Knowledge Development}

Knowledge is an important dimension of cultural competence that is useful to enable international students to improve their employment opportunities in Australia. It is essential that international students develop knowledge about employment rules, regulations and restrictions pertaining to international workers in the host country, to advance employability (Blackmore et al., 2014; Gribble \& McRae, 2017; Sangganijanavanich, Lenz, \& Cavazos, 2011). Without such knowledge, international students may find it challenging to fully understand workplace agreements, 
negotiate fair conditions of work with their employers, or stand up to their employers when unreasonable requests are made of them during their employment (Reilly, 2012). Nyland et al. (2009) emphasise that many international students have not been adequately informed of their labour rights. According to Sangganijanavanich et al. (2011), international students' career options and decisions were affected by their limited knowledge of the rules and regulations around their employment, which in turn created anxiety for the students.

Equally critical is to acquire pre-entry information about the Australian labour market and the global graduate market (Gribble et al., 2015), as this enables international students to develop a realistic understanding of employment opportunities in the country prior to and post-graduation. Many international students have unrealistic expectations of the level of effort required to find employment after graduating, which may include gaining work experience, learning how to articulate their knowledge, skills and experience to prospective employers, and gradually developing their employability (Gribble et al., 2015). Also important is their understanding of the notion of employability in the Australian context, which may be different in other countries and cultures; for example, in Australia, more focus is placed upon developing non-technical skills and gaining relevant work experience, rather than students restricting themselves to the discipline content (Jackson, 2017). This will help international students to ensure they have some practical experience when searching for jobs in Australia.

It is also essential for international students to build knowledge about the Australian workplace culture as this will demonstrate to prospective employers that they can integrate well into their workplace. This cultural competence capability has become more significant with the increasing emphasis on the cultural fit of job applicants (Rivera, 2012). Jackson (2017) illuminates international students' difficulties in adjusting to the Australian work setting during their study-integrated learning; for example, the necessity of grasping the code of conduct, expectations of employers, established workplace processes, hierarchical structure in the area they are situated, business etiquette, and who they are supposed to ask about what. Sangganijanavanich et al. (2011) contend that a lack of familiarity with the US culture was likely to impede international students' ability to compete with their domestic counterparts. These differences were present throughout the job search process and most obvious during job interviews. International students reported struggling with different communication styles and behaviours that may influence their chance of employment, such as non-verbal communication (e.g. how to conduct oneself during an interview, and what are culturally appropriate and accepted behaviours) and verbal communication (e.g. what to share and how much information to share).

Another useful strategy for international students is to build more in-depth knowledge about the wider Australian society as well as other cultures, given the increasing cultural diversity in the Australian workplace. This knowledge is necessary because it can allow international students to integrate more successfully and avoid crosscultural tensions. Multiple factors contribute to international students' "cultural enclosure" when studying in Australia. International students, especially those from China or Vietnam, tend to remain in their comfort zones (e.g. mixing with others from 
their country) instead of actively mixing with other cultures and/or local students, often because of language barriers (Wearing, Le, Wilson, \& Arambewela, 2015; Xiao $\&$ Petraki, 2007). Students who want to engage more with local people and students face a couple of barriers; for example, studying in a campus where there are a large number of international students minimises their opportunity to interact with local students (Wearing et al., 2015). Cross-cultural interactions between international students and others are further inhibited by international students' perceptions of domestic students' actions and attitudes as showing superiority towards them (Tran $\&$ Pham, 2016). Additionally, many international students tend to combine work and study and spend minimal time on campus; or they have established friendship groups (with other international students) and, therefore, are not motivated to expand their networks to include domestic students (Gribble et al., 2015). International students' accommodation choices can also minimise their cross-cultural interactions, as due to the limited and costly campus accommodation they prefer to share accommodation with other international students, who are often from the same language group (Gribble at al., 2015). International students from some countries (such as China) are also found to have limited knowledge about the values, common faiths or political views held by students from other countries, and this minimises the cross-cultural communication skills of those groups of students (Xiao \& Petraki, 2007).

Stronger interpersonal connections between international students and domestic students or community members in Australia can be established through living in "homestay" accommodations (Gribble, Blackmore, \& Rahimi, 2015). Such connections can allow international students to not only have more exposure to the host country's culture, but also acquire more information about the complexities and subtle nuances of the country's cultural context (Wang et al., 2014). Active participation in the Work Integrated Learning (WIL) programme is another effective option. Gribble and McRae (2017) highlight multiple benefits of the WIL programme for international students, in both Australia and Canada, that include exposure to local work culture (including the workplace culture) and everyday cross-cultural interactions with colleagues. The programme also helps international students become familiar with the country's policy, regulations and procedures; and be exposed to real-world scenarios rather than simply receiving instruction, such as having the opportunity to experience how to communicate with culturally diverse clients.

Last but not least in regard to the knowledge aspect of cultural competence is the necessity for international students to build their proficiency in English. The focus on improving these students' English proficiency to boost their employment opportunities is not new (Blackmore et al., 2014; Gribble et al., 2015; Wang et al., 2014; Huang, 2016), as doing so leads to better job opportunities for the students. Developing English proficiency also enables international students to better comprehend their workplace agreements, negotiate fair work conditions with employers, or deal effectively with employers' unreasonable requests (Reilly, 2012). Yet, the question is how international students can achieve this aim, in light of the number of barriers they are facing while living and studying in Australia. For the many international students who continue to live, study and work in their native language, and have little trouble in communicating with friends and families in their home countries, thanks to social 
media (Gribble et al., 2015), there may be few opportunities to improve their English skills. Furthermore, it was found that students with limited English proficiency are less likely to engage with native speakers, find part-time work that involves speaking English, join clubs, or participate in extra-curricular activities, which are the forms of social capital employers are seeking in applicants (Blackmore et al., 2014). One strategy that international students can employ to improve their English skills is finding more opportunities to hang out with local students or choosing a mixed class of both international and local students (Tran \& Pham, 2016).

In particular, Gribble et al. (2017) suggest that homestay arrangements can be a good strategy as it allows international students to live with Australian families and have some shared activities together, such as meals or family outings. International students choosing homestay arrangements often found that this experience had been instrumental in developing their English proficiency. The homestay arrangement, as Gribble et al. (2017) argue, is a useful way to enhance social integration into the broader host community, which is linked to a successful overseas sojourn for international students.

\section{Enhancing Employability Through Social Initiatives, Flexibility, Recognition of Multiple Worldviews and Emotional Stability}

In the case of international students, the ability to carry out social initiatives, which is an important dimension of cultural competence, is pertinent to enhancing employment opportunities in Australia. One such social initiative is to "perform migrancy", as Robertson (2016) conceptualises, which can help to ease employers' concerns about international students' long-term work commitment in Australia (Gribble \& McRae, 2017; McFadden \& Seedorff, 2017). According to Robertson, "performing migrancy" refers to international students' efforts to establish themselves as "true" migrants instead of maintaining the sojourner identities that have often been used to view international students. In order to do this, international students seek to display not only the cultural competencies required for professional skilled work, but also the long-term commitment to living and working in Australia. This social initiative can be performed in two directions. On the one hand, international students seek to develop particular habits and practices in the workplace, both cultural competencies and cultural practices, to "prove" their worth as a worker and demonstrate their commitment to professionalism and a permanent stay. On the other hand, they also attempt to distance themselves from stereotypes of student-workers, or from the perceived "masses" of fellow students within the urban environment who are willing to do unskilled work, and from framings of students as "backdoor"- therefore, undesirable-migrants (Robertson 2013). Robertson (2013) discusses the case of an Indian business graduate who described himself as different from other international students because, according to him, those students are not serious about study 
and are using their student visas to do unskilled work. Blaming those student-workers as "ruining it for everybody", this Indian graduate wanted to show his commitment to a permanent stay in Australia as a working professional who wanted "to stay here and enrich this country, not work some rubbish job" (Robertson, 2013, pp. 2282-2283).

Demonstrating commitment to professionalism should be viewed as another critical social initiative that international students can adopt to boost their employment opportunities in Australia. Gribble and McRae (2017) point out that participating in the WIL programme gives international students a good opportunity to demonstrate to prospective employers that they are competent and can be trusted to commit to the workplace. Blackmore, Gribble, \& Rahimi's study (2015) details how a female international Chinese student earned the job she wanted in Australia, as follows. She did multiple menial jobs during her first few years of study in Australia to pay her bills; for example, working in a bakery, or selling credit cards in a shopping centre. Being aware of the importance of obtaining discipline-specific work experience in order to be employable in Australia, and of the employment challenges caused by her visa status, the student decided to spend her summer holidays completing a threemonth internship with an international financial credit rating company in China. This internship allowed her to then secure a position as a consultant with a multinational media firm in Australia and enabled her to expand her networks to include the big accounting company that was her dream workplace. This student's strategy can be viewed as a critical social initiative in boosting her employment prospects. She worked closely with the manager at the big accounting company, spending the weekends at the company as if she was working there. These efforts demonstrated her ability to establish effective cross-cultural relationships and her strong commitment to professionalism. Eventually, she was employed at the company after only an informal interview because the people there had already recognised her proactive attitudes and activities.

To boost employability, international students also need to demonstrate some other important aspects of cultural competence: flexibility (Shaffer et al., 2006; Van de Zee \& Van Oudenhoven, 2000) and the ability to recognise different worldviews (SNAICC, 2012). According to Sangganijanavanich et al. (2011), international students may encounter job search difficulties if they continue to maintain their ethnic habitus in such a way that is incompatible with the new workplace culture. For example, Chinese students can find it challenging to highlight their own achievements during the job interview in the USA because back in their home country, it is considered as being boastful and offensive to talk in that manner. Maintaining this ethnic habitus in the job interview may lead the interviewers to judge that these students are not confident and have low self-esteem, as US interviewers often highly value applicants' self-confidence and the can-do attitudes (Leri, 2009). Adjusting one's ethnic habitus can lead to feelings of discomfort, incongruence and awkwardness (Sangganijanavanich et al., 2011); however, being able to do this in a relaxing manner can improve students' chances of employment. As Robertson's study (2016) highlights, it is important to cultivate the performance of a desirable, culturally competent professional worker through improvement not only of their 
English proficiency, but also of the way they behave and present themselves in the Australian workplace.

Emotional stability is one dimension of cultural competence that can enable international students to enhance employability when searching for work in Australia. Both the literature and media have reported cases of international students experiencing shock, or feeling ashamed, when they found out that they had little choice but to perform low-level types of jobs in Australia (Nguyen \& Nguyen, 2017; Nyland et al., 2009). Blackmore et al. (2014) observe that international graduates often have high expectations of post-study employment; for example, in their study, many international accounting students aimed to work for large multinational firms, and many international nursing students aimed to work in major metropolitan hospitals. Because those very high expectations can lead international students to be disappointed, the authors suggest that looking for multiple pathways and working for a smaller firm or a regional hospital should be considered, as they can lead to other opportunities later. On the other hand, Nyland et al. (2009) found that some international students were more aware of what their circumstances in Australia would be, and they were more accepting and less ashamed of the lowering of their employment status. For instance, an Indian student commented that "back home I am an officer .... I'm a magistrate there, so I have a designation and have another status there, and here I'm a student without any money. It's totally different" (Nyland et al., 2009, pp. 11-12). As the authors pointed out, this student appeared more accepting about shifting from a position of power and influence to being a student without money. The fact that he seems less surprised than some others about his new status gives the impression that his experience was in line with his expectations and demonstrates his emotional stability in adjusting himself to the new situation in Australia.

\section{Becoming More Employable Through Self-reflection}

Self-reflection (Olson et al., 2016) is a salient dimension of cultural competence that international students can adopt to become more employable in Australia. In order to enhance employment opportunities, it is essential for international students to be aware of their strengths and promote them during the job search process. These include not only personal advantages (e.g. appearance or linguistic skills), but also cultural strengths (e.g. common positive perceptions about their own cultures, such as a strong work ethic). Robertson (2016) introduces what she terms as "performing ethnicity" as a strategy for international students to become more employable, based on their ethnic appearance. For her, "performing ethnicity" occurs when students are employed at unskilled or low-skilled labour levels within industries of cosmopolitan consumption like the restaurant business (see also Campbell et al., 2016). Robertson (2016) argues that ethnicity becomes an important source for "non-white" students to find employment in Australia because of their capacity to "pass" as particular ethnicities for the gaze of the cosmopolitan Western consumer. For example, a 
popular Turkish restaurant hired fair-skinned Indian and Nepalese female international students as staff because they looked Turkish to Western customers; and some Korean-owned restaurants instructed Korean student-workers to pretend to customers that they were Japanese (Robertson, 2016). However, it should be noted that poor pay is common for employees in ethnic cafés or restaurants (Campbell et al., 2016; Clibborn, 2015).

International students should also closely examine their other strengths to be able to demonstrate the significant benefits that they can offer employers, when competing with domestic candidates for jobs in Australia. Positive perceptions about international students often fall on their position as "a resource for foreign relations as a network of graduates", especially "quality students from the premium end of markets" who will "provide more influential diplomatic and business ties" (Koehne, 2006 , p. 246). International students are also perceived to be hard working and less likely to quit if they confront challenges (Gribble et al., 2015). Knowledge of language and culture in key markets is another advantage (Gribble et al., 2015). Sangganijanavanich et al. (2011) reveal that during the job search process, international students in the US tended to discover the personal uniqueness that distinguished them from their domestic counterparts; for example, their cultural diversity and multilingual ability. Students believed that they brought cultural diversity to their potential US employers by offering unique perspectives and approaches from a cross-cultural point of view, and the ability to better comprehend global trends and international issues. They agreed that their multilingual ability had helped them to be competitive in the job market and because of this ability, they often searched for positions in companies with a mission and vision focused on the global economy or international markets. Gribble and McRae (2017) also highlight benefits that Asian international students can offer; for instance, knowledge of Asian culture and business practices, and personal relationships and connections with relevance to Asia.

\section{Conclusion}

This chapter identifies the dimensions of cultural competence that can enable international students to enhance employability when looking for work in Australia. These dimensions include knowledge, social initiatives, flexibility, the ability to recognise multiple worldviews, emotional stability and self-reflection. While international students' employment outcomes certainly depend on multiple factors, the importance of developing international students' cultural competence to promote employability should be emphasised.

Dimensions of cultural competence as identified in this chapter reflect Tomlinson's (2017) conceptualisation of employability through the capital lens. Specifically, those dimensions can assist international students to build necessary forms of capital that are necessary to build employability. Cultural competence allows international students to develop social capital such as social relations with native speakers that benefits their job search process. Cultural competence also assists international 
students to acquire cultural capital such as cultural knowledge, behaviours and awareness that make them more attractive to employers. Self-reflection about their cultural backgrounds and strengths also enable international students to develop identity capital that make them more outstanding among other job applicants in Australia. At the same time, the development of emotional stability and flexibility during the job search process enhances international students' psychological capital that is beneficial for promoting employability. Eventually, successful performance of the different dimensions of cultural competence can help international students to draw more effective and realistic job search strategies, become more resilient in the process and, in particular, present themselves as strong and suitable candidates for jobs in Australia. This research emphasises the necessity for educational institutions in Australia to develop cultural competence training for international students that aims to promote employability. At the same time, the responsibility also rests with international students to make necessary efforts to become culturally competent, as this will effectively benefit their job search process in Australia.

\section{References}

Ang, S., Van Dyne, L., \& Koh, C. (2006). Personality correlates of the four-factor model of cultural intelligence. Group \& Organization Management, 31(1), 100-123.

Baumann, U., \& Vialleton, E. (2017). Intercultural communicative competence and employability in the languages curriculum at the Open University UK. In E. Císlerová \& M. Štefl (Eds.), Intercultural communicative competence: A competitive advantage for global employability (pp. 35-45). Prague: Czech Technical University.

Bennett, J. M. (2009). Transformative training: Designing programs for culture learning. In M. Moodian (Ed.), Contemporary leadership and intercultural competence (pp. 95-110). Thousand Oaks, CA: SAGE.

Betancourt, J. R., Green, A. R., Carrillo, J. E., \& Park, E. R. (2005). Cultural competence and health care disparities: Key perspectives and trends. Health Affairs, 24(2), 499-505.

Birrell, B. (2006). Implications of low English standards among overseas students at Australian universities. People and Place, 14(4), 53-64.

Blackmore, J., Gribble, C., Farrell, L., Rahimi, M., Arber, R., \& Devlin, M. (2014). Australian international graduates and the transition to employment. Deakin University.

Blackmore, J., Gribble, C., \& Rahimi, M. (2015). International education, the formation of capital and graduate employment: Chinese accounting graduates' experiences of the Australian labour market. Critical Studies in Education, 1-20.

Bond, S., Areepattamannil, S., Brathwaite-Sturgeon, G., Hayle, E., \& Malekan, M. (2007). Northern lights: International graduates of Canadian institutions. Canadian Bureau for International Education. Retrieved from https://en.copian.ca/library/research/ccl/northern_lights/northern_lig hts.pdf.

Bourdieu, P. (1990). The logic of practice. London: Blackwell.

Bourdieu, P. (1991). Language and symbolic power. Cambridge: Polity Press.

Busch, D. (2009). What kind of intercultural competence will contribute to students' future job employability? Journal of Intercultural Education, 20(5), 429-438.

Campbell, I., Boese, M., \& Tham, J. (2016). Inhospitable workplaces? International students and paid work in food services. Australian Journal of Social Issues, 51(3), 279-298.

Campinha-Bacote, J. (2016) The Process of Cultural Competence in the Delivery of Healthcare Services: A Model of Care. Journal of Transcultural Nursing, 13(3), 181-184 
Carpenter, L. (2016). The development of cultural competence in social work practice and education. Master of Social Work Clinical Research Papers. Paper 568.

Carroll, J., \& Ryan, J. (Eds.). (2005). Teaching international students: Learning for all. London: Routledge.

Clibborn, S. (2015). 7-Eleven: Amnesty must apply to all exploited workers. Sydney Morning Herald. Retrieved from https://www.smh.com.au/business/careers/7eleven-amnesty-must-applyto-all-20150908-gjheyp.html.

Cross, T. L., Bazron, B. J., Dennis, K. W., \& Isaacs, M. R. (1989). Towards a culturally competent system of care: A monograph on effective services for minority children who are severely emotionally disturbed. Washington, DC: Child and Adolescent Service System Program Technical Assistance Center, Georgetown University Child Development Center.

Deardoff, D., \& Jones, E. (2012). Intercultural competence. In D. Deardoff, H. Wit, J. Heyl, \& T. Adams (Eds.), The SAGE handbook of international higher education. Thousand Oaks: SAGE.

Department of Education and Training, Australian Government. (2019). International student enrolment data 2019. Retrieved from https://internationaleducation.gov.au/research/Internati onal-Student-Data/Documents/MONTHLY\%20SUMMARIES/2019/Feb\%202019\%20Mont hlyInfographic.pdf.

Department of Home Affairs. (2019a). Student visa (Subclass 500). Retrieved from https://immi. homeaffairs.gov.au/visas/getting-a-visa/visa-listing/student-500\#About.

Department of Home Affairs. (2019b). Postgraduate research sector visa (Subclass 574). Retrieved from https://immi.homeaffairs.gov.au/visas/getting-a-visa/visa-listing/repealed-visas/postgradu ate-research-sector-574.

Devos, A. (2003). Academic standards, internationalization, and the discursive construction of "The International Student." Higher Education Research \& Development, 22(3), 155-166.

Fielden, J. (2007). Global horizons for UK universities. London: CIHE.

Fugate, M., Kinicki, A., \& Ashforth, B. (2004). Employability: A psycho-social construct, its dimensions and applications. Journal of Vocational Behavior, 65, 14-38.

Gardner, H. (2004). How education changes: Considerations of history, science, and value. In M. Suarez-Orozco \& D. B. Qin-Hilliard (Eds.), Globalisation: Culture and education in the new millennium (pp. 235-258). Berkeley: University of California Press.

Gribble, C. (2014). Employment, work placements and work integrated learning of international students in Australia. Research Digest Series. Melbourne: IEAA.

Gribble, C., \& Blackmore, J. (2012). Re-positioning Australia's international education in global knowledge economies: Implications of shifts in skilled migration policies for universities. Journal of Higher Education Policy and Management, 34(4), 341-354.

Gribble, C., Blackmore, J., \& Rahimi, M. (2015). Challenges to providing work integrated learning to international business students at Australian universities. Higher Education, Skills and WorkBased Learning, 5(4), 401-416.

Gribble, C., Blackmore, J., \& Rahimi, M. (2017). International students and post study employment: The impact of university and host community engagement on the employment outcomes of international students in Australia. In C. Gomes \& L. Tran (Eds.), International student connectedness and identity: Transnational perspectives. Education Series. Berlin: Springer.

Gribble, C., \& McRae, N. (2017). Creating a climate for global WIL: Barriers to participation and strategies for enhancing international students' involvement in WIL in Canada and Australia. In G. Barton \& K. Hartwig (Eds.), Professional learning in the work place for international students. Springer International Publishing AG.

Harrison, G., \& Turner, R. (2011). Being a "Culturally competent" social worker: Making sense of a murky concept in practice. British Journal of Social Work, 41, 333-350.

Hawthorne, L. (2010). "Two-step migration"? Labor market outcomes for international student migrants to Australia. Asian and Pacific Migration Journal, 19(1), 5.

Hawthorne, L., \& To, A. (2014). Australian employer response to the study-migration pathway: The quantitative evidence 2007-2011. International Migration, 52(3), 99-115. 
Holmes, L. (2013). Competing perspectives on graduate employability: Possession, position or process? Studies in Higher Education Journal, 38(4), 538-554.

Huang, C. (2016). International students in Australia struggle on many fronts. Sydney Morning Herald. Retrieved from https://www.smh.com.au/comment/international-students-in-australiastruggle-on-many-fronts-20160901-gr66dx.html.

Jackson, D. (2017). Exploring the challenges experienced by international students during workintegrated learning in Australia. Asia Pacific Journal of Education, 37(3), 344-359.

Jones, E. (2013). Internationalisation and employability: The role of intercultural experiences in the development of transferable skills. Public Money and Management, 33(2), 95-104.

Koehne, N. (2006). (Be)Coming, (Be)Longing: Ways in which international students talk about themselves. Discourse: Studies in the cultural politics of education, 27(2), 241-257.

Lambert, O. (2017). Special Broadcasting Service (SBS) investigation finds international students are being exploited. Retrieved from https://www.news.com.au/finance/work/at-work/sbs-invest igation-finds-international-students-are-being-exploited/news-story/f9213c5acff30ff76affcf9c $\mathrm{b} 4 \mathrm{e} 0 \mathrm{cc} 38$.

Leri, P. (2009). Interviewing across cultures. In M. A. Thompson (Ed.), The global resume and cv guide: Advice from the experts in executive search and recruitment (pp. 235-248). Retrieved from https://fordschool.umich.edu/downloads/InterviewCrossCultures.pdf.

Marginson, S., Nyland, C., Sawir, E., \& Forbes-Mewett, H. (2010). International student security. Cambridge: Cambridge University Press.

McFadden, A., \& Seedorff, L. (2017). International student employment: Navigating immigration regulations, career services and employer considerations. New Directions for Student Services, $158,37-48$.

McQuaid, R., \& Lindsay, C. (2005). The concept of employability. Urban Studies, 42(2), 197-219.

Murray, D., Blackmore, J., Gribble, C., \& Hall, R. (2012). Internships and work placement opportunities for international students in Victoria. Melbourne: International Education Association of Australia.

Nguyen, T., \& Nguyen, O. (2017). Exclusive: Exploitation of Vietnamese students rampant among Melbourne business. SBS. Retrieved from https://www.sbs.com.au/yourlanguage/vietnamese/en/ explainer/exclusive-exploitation-vietnamese-students-rampant-among-melbourne-businesses.

Nilsson, P., \& Ripmeester, N. (2016). International student expectations: Career opportunities and employability. Journal of International Students, 6(2), 614-631.

Nunes, S., \& Arthur, N. (2013). International students' experiences of integrating into the workforce. Journal of Employment Counselling, 50, 34-45.

Nyland, C., Forbes-Mewett, H., \& Marginson, S. (2010). The international student safety debate: Moving beyond denial. Higher Education Research \& Development, 29(1), 89-101.

Nyland, C., Forbes-Mewett, H., Marginson, S., Ramia, G., Sawir, E., \& Smith, S. (2009). International student-workers in Australia: A new vulnerable workforce. Journal of Education and Work, 22(1), 1-14.

Olson, R., Bidewell, J., Dune, T., \& Lessey, N. (2016). Developing cultural competence through self-reflection in interprofessional education: Findings from an Australian university. Journal of Interprofessional Care, 30(3), 347-354.

Pollack, S. (2004). Anti-oppressive social work practice with women in prison: Discursive reconstructions and alternative practices. British Journal of Social Work, 34, 693-707.

Pon, G. (2009). Cultural competency as new racism: An ontology of forgetting. Journal of Progressive Human Services, 20(1), 59-71.

Potgieter, I., \& Coetzee, M. (2013). Employability attributes and personality preferences of postgraduate business management students. SA Journal of Industrial Psychology 39(1).

Razack, N., \& Jeffery, D. (2002). Critical race discourse and tenets for social work. Canadian Social Work Review, 19(2), 257-271.

Reilly, A. (2012). Protecting vulnerable migrant workers: The case of international students. Australian Journal of Labour Law, 25, 181-208. 
Rivera, L. (2012). Hiring as cultural matching: The case of elite professional service firms. American Sociological Review, 77(6), 999-1022.

Robertson, S. (2011). Cash cows, backdoor migrants, or activist citizens? International students, citizenship, and rights in Australia. Ethnic and Racial Studies, 34(12), 2192-2211.

Robertson, S. (2013). Campus, city, networks and nation: Student-migrant activism as socio-spatial experience in Melbourne, Australia. International Journal of Urban and Regional Research, 37(3), 972-988.

Robertson, S. (2016). Student-workers and tourist-workers as urban labour: Temporalities and identities in the Australian cosmopolitan city. Journal of Ethnic and Migration Studies, 42(14), 2272-2288.

Sangganijanavanich, V., Lenz, S., \& Cavazos, J. (2011). International students' employment search in the United States: A phenomenological study. Journal of Employment Counselling, 48(1), $17-26$.

Shaffer, M., Harrison, D., Gregersen, H., \& Black, S. (2006). You can take it with you: Individual differences and expatriate effectiveness. Journal of Applied Psychology, 91, 109-125.

Sherwood, J., \& Russell-Mundine, G. (2017). How we do business: Setting the agenda for cultural competence at The University of Sydney. In J. Frawley, S. Larkin, \& J. A. Smith (Eds.), Indigenous pathways, transitions and participation in higher education: From policy to practice (pp. 133150). Singapore: Springer.

SNAICC. (2012). Aboriginal and Torres Strait Islander children's cultural needs. SNAICC resource service. Retrieved from www.snaicc.org.au.

Stark, J. (2005). Hello stranger. The Age. Retrieved from https://www.theage.com.au/news/national/ hello-stranger/2005/09/18/1126981943642.html. Accessed December 18, 2017.

Tomlinson, M. (2017). Forms of graduate capital and their relationship to graduate employability. Education + Training, 59(4), 338-352.

Tran, L. (2009). An acculturation dilemma for Asian International Students in Australia: The case of Vietnamese International Students. In ISANA Proceedings. Retrieved from https://isana.procee dings.com.au/docs/2009/paper_tran2.pdf.

Tran, L., \& Nyland, C. (2011). International vocational education and training-The migration and learning mix. Australian Journal of Adult Learning, 51(1), 8-31.

Tran, L., \& Pham, L. (2016). International students in transnational mobility: Intercultural connectedness with domestic and international peers, institutions and the wider community. Compare: A Journal of Comparative and International Education, 46, 560-581.

Van De Zee, K., Zaal, J., \& Piekstra, J. (2003). Validation of the Multicultural personality questionnaire in the context of personnel selection. European Journal of Personality, 17(1), $77-100$.

Van der Zee, K., \& Van Oudenhoven, J. (2000). The multicultural personality questionnaire: A multidimensional instrument of multicultural effectiveness. European Journal of Personality, 14, 291-309.

Wang, K. T., Heppner, P. P., Wang, L., \& Zhu, F. (2014). Cultural intelligence trajectories in new international students: Implications for the development of cross-cultural competence. International Perspectives in Psychology: Research, Practice, Consultation, 4(1), 51-65.

Wearing, A., Le, H., Wilson, R., \& Arambewela, R. (2015). The international student's experience: An exploratory study of students from Vietnam. The International Education Journal: Comparative Perspectives, 14(1).

Webb, G. (2005). Internationalization of curriculum: An institutional approach. In J. Carroll \& J. Ryan (Eds.), Teaching international students: Improving learning for all. London: Routledge.

Wise, A. (2009). It's just an attitude that you feel: Inter-ethnic habitus before the Cronulla riots. In G. Noble (Ed.), Lines in the sand: The Cronulla riots, multiculturalism and national belonging (pp. 1-4). Sydney: Sydney Institute of Criminology Press.

Xiao, H., \& Petraki, E. (2007). An investigation of Chinese students' difficulties in intercultural communication and its role in ELT. Journal of Intercultural Communication, 13, 6.

Yorke, M. (2006). Employability in higher education: What it is, what it is not. York: The Higher Education Academy. 
Tran Nguyen is Associate Lecturer at the National Centre for Cultural Competence, The University of Sydney. She obtained a Master of Philosophy in Development Studies from University of Cambridge and a Ph.D. in Sociology from Macquarie University. Tran's research interests include international migration, inter-ethnic relations, cultural competence, employment services, and organisational studies.

Donna Hartz identifies as a descendant of her grandmother's people, the Kamillaroi nation. She is a midwife and nurse with 34 years' experience as a clinician, educator, lecturer, manager, consultant, and researcher. During this time, she has worked at a variety of tertiary and metropolitan health services and universities within New South Wales. Donna is currently an Associate Professor in Midwifery at Charles Darwin University.

Open Access This chapter is licensed under the terms of the Creative Commons Attribution 4.0 International License (http://creativecommons.org/licenses/by/4.0/), which permits use, sharing, adaptation, distribution and reproduction in any medium or format, as long as you give appropriate credit to the original author(s) and the source, provide a link to the Creative Commons license and indicate if changes were made.

The images or other third party material in this chapter are included in the chapter's Creative Commons license, unless indicated otherwise in a credit line to the material. If material is not included in the chapter's Creative Commons license and your intended use is not permitted by statutory regulation or exceeds the permitted use, you will need to obtain permission directly from the copyright holder. 